\title{
UJI EFEK ANALGETIK EKSTRAK ETANOL DAUN NANGKA (Artocarpus heterophyllus Lam.) TERHADAP MENCIT (Mus musculus) YANG DIINDUKSI ASAM ASETAT
}

\author{
Nielma Auliah ${ }^{1}$, Ari Aprianto Latuconsina ${ }^{2}$, Muthmainnah Thalib ${ }^{3}$ \\ ${ }^{1,2,3}$ STIKes Mega Rezky Makassar
}

Email Korespondensi: Nielmaauliah@gmail.com

\begin{abstract}
ABSTRAK
Telah dilakukan penelitian dengan judul "Uji Efek Analgetik Ekstrak Etanol Daun Nangka (Artocarpus heterophyllus Lam.) Terhadap Mencit (mus musculus) Yang Diinduksi Asam Asetat. Analgetik atau obat penghilang nyeri adalah obat-obat yang mengurangi atau melenyapkan rasa tanpa menghilangkan kesadaran. Salah satu tanaman tradisional yang biasa digunakan secara empiris adalah daun nangka (Artocarpus heterophyllus Lam.). Penelitian ini bertujuan untuk mengetahui efek analgetik ekstrak etanol daun nangka (Artocarpus heterophylus Lam.) pada dosis $100 \mathrm{mg} / \mathrm{kgBB}, 300 \mathrm{mg} / \mathrm{kgBB}$ dan 600 $\mathrm{mg} / \mathrm{kgBB}$ pada mencit putih jantan (Mus musculus) yang diinduksi asam asetat. Penelitian ini merupakan penelitian eksperimental dan menggunakan metode induksi kimia. Hasil penelitian yang diperoleh berupa \% proteksi penghambatan geliat ekstrak etanol daun nangka (Artocarpus heterophyllus Lam.) dengan dosis 100mg/kgBB (28,79\%); $300 \mathrm{mg} / \mathrm{kgBB}(53,31 \%) ; 600 \mathrm{mg} / \mathrm{kgBB}(60,70 \%)$. Dari hasil penelitian yang telah dilakukan dapat disimpulkan bahwa ekstrak etanol daun nangka (Artocarpus heterophyllus Lam.) memiliki efek analgetik tertinggi pada dosis $600 \mathrm{mg} / \mathrm{kgBB}$ mempunyai persen proteksi sebesar yaitu $66,70 \%$.
\end{abstract}

Kata Kunci : Analgetik, daun nangka (Artocarpus heterophyllus Lam.) Asam Asetat. 


\begin{abstract}
Research has been carried out with the title "Test of the Analgetic Effect of Ethanol Extract of Jackfruit Leaves (Artocarpus heterophyllus Lam.) On Acetic Acid-induced Mice (mus musculus). Analgesics or painkillers are drugs that reduce or eliminate taste without losing consciousness. One of the traditional plants commonly used empirically is jackfruit leaves (Artocarpus heterophyllus Lam.). This study aims to determine the analgetic effect of ethanol extract of jackfruit leaves (Artocarpus heterophylus Lam.) At a dose of $100 \mathrm{mg} /$ $\mathrm{kgBB}, 300 \mathrm{mg} / \mathrm{kgBB}$ and $600 \mathrm{mg} / \mathrm{kgBW}$ on acetic acid induced male mice (Mus musculus). This research is an experimental study and uses the chemical induction method. The results obtained in the form of\% protection inhibition stretching ethanol extract of jackfruit leaves (Artocarpus heterophyllus Lam.) At a dose of 100mg / kgBB (28.79\%); $300 \mathrm{mg} / \mathrm{kgBB}(53.31 \%) ; 600 \mathrm{mg} / \mathrm{kgBB}(60.70 \%)$. From the results of the research that has been done it can be concluded that the ethanol extract of jackfruit leaves (Artocarpus heterophyllus Lam.) Has the highest analgesic effect at a dose of 600mg / $\mathrm{kgBW}$ having a percentage of protection of $66.70 \%$.
\end{abstract}

Keywords: Analgetic, jackfruit leaf (Artocarpus heterophyllus Lam.) Acetic Acid.

\section{PENDAHULUAN}

Pengobatan menggunakan

tanaman obat telah ada dan dikenal oleh masyarakat Indonesia sejak zaman dahulu. Banyak tanaman obat yang sudah dilaporkan mempunyai efek terapi untuk beberapa penyakit, namun pengetahuan tentang khasiat dan keamanan obat alami ini kebanyakan hanya bersifat empiris dan belum diuji secara ilmiah (Widya, et al.,2014)., Penggunaan obat tradisional secara umum dinilai lebih aman dibandingkan obat modern, hal ini disebbkan karena obat tradisional memiliki efek samping yang relatif sedikit dari pada obat modern (Susianyo Panegstu, et al.,2016). Salah satu tanaman tradisional yang biasanya digunakan secara empiris adalah daun nangka (Artocarpus heterophyllus Lam.) untuk mengobati demam, bisul, luka dan beberapa jenis penyakit kulit terutama bakteri Staphylococcus aureus yang merupakan bakteri pathogen alami pada tubuh manuia penyebab berbagai infeksi kulit yang mampu mengancam jiwa ( I Wayan, et al., 2010). Hasil skrining fitokimia pada daun nangka (Artocarpus heterophyllus Lam.) yang telah dilakukan dan diketahui mengandung senyawa flavonoid, saponin, dan tanin yang berperan sebagai antibakteri, antidiare, demam, bisul, penyakit kulit, analgetik (Rahmi, et al., 2017). Daun nangka (Artocarpus heterophyllus Lam.) mengandung flavonoid. Flavonoid berperan sebagai analgetik yang mekanisme kerjanya melindungi membran lipid dari kerusakan dan menghambat enzim ciclooxigenase I yang merupakan jalur pertama sintesis mediator nyeri seperti prostaglandin (Meustika dewi, et al., 2014). Analgetik atau obat penghilang nyeri adalah obat- 
obat yang mengurangi atau melenyapkan rasa tanpa menghilangkan kesadaran (Sariana, 2011). Rasa sakit atau nyeri merupakan petanda ada bagian tubuh yang bermasalah, yang merupakan suatu gejala, yang fungsinya adalah melindungi serta memberikan tanda bahaya tentang adanya gangguan-gangguan didalam tubuh seperti peradangan , infeksi kuman atau kejang otot. Rasa nyeri timbul karena adanya rangsangan mekanis ataupun kimiawi yang dapat menimbulkan kerusakan pada jaringan dan melepaskan zat-zat tertentu yang disebut mediator (perantara) nyeri seperti bradikinin, histamin, serotonin, dan prostaglandin (Meustika dewi, 2014). Berdasakan uraian diatas, penulis bermaksud melakukan uji efek ekstrak etanol daun nangka (Artocarpus heterophyllus Lam.) pada dosis pada dosis $100 \mathrm{mg} / \mathrm{kgBB}, 300$ $\mathrm{mg} / \mathrm{kgBB}$ dan $600 \mathrm{mg} / \mathrm{kgBB}$ pada mencit (Mus musculus) yang diinduksi asam asetat.

\section{METODE PENELITIAN}

Bahan Penelitian Daun yang (Artocarpus heterophyllus Lam.) segar yang baru diperoleh dari kelurahan Antang, kecamatan Manggala, Kota Makassar. Hewan uji yang digunakan dalam penelitian ini berupa mencit putih jantan (Mus musculus), berat 20- 30 gram, umur 2-3 bulan sebanyak 15 ekor lalu dibagi menjadi 5 kelompok yang diperoleh dari pasar hewan kota Makassar. Bahan kimia yang digunakan yaitu Aquadest, Asam Asetat 0,1\% Etanol
96\%, Asam Mefenamat $500 \mathrm{mg}$, dan $\mathrm{NaCMC} 0,5 \%$.

Alat Penelitian Alat yang digunakan yaitu bejana maserasi, timbangan analitik (OHAUS $®)$ ), cawan porselin (IWAKI PIREX®), pipet tetes (Pudak), kanula (New Blunt Cannula), jarum oral, beaker glass (IWAKI PIREX®), gelas ukur (IWAKI PIREX® ), stopwatch.

\section{CARA KERJA}

\section{Pembuatan Ekstrak Etanol daun nangka (Artocarpus heterophyllus Lam.)}

Simplisa daun nangka (Artocarpus heterophyllus Lam.). Ditimbang sebanyak 500 gram kemudian dimasukkan ke dalam bejana maserasi yang ditambahkan etanol 96\% sebanyak 4 liter. Setelah 3 hari cairan penyari diganti dengan etanol 96\% yang baru sebanyak 4 liter. penggantian cairan penyari dilakukan sebanyak 1 kali setiap 3 hari dengan jumlah penyari yang sama. Penggantian cairan dilakukan sebanyak 3 kali. Ekstrak cair etanol $96 \%$ yang diperoleh kemudian dikumpulkan dan diuapkan hingga diperoleh ekstrak kental. Pembuatan Suspensi Na-CMC 0,5\%

Ditimbang Na-CMC 0,5 gram dan dimasukan sedikit demi sedikit kedalam $50 \mathrm{ml}$ air panas sambal diaduk dengan pengaduk hingga terbentuk larutan kolodial dan cukupkan volumenya hingga $100 \mathrm{ml}$ kemudian disterilkan menggunakan autoklaf 15-20 menit. Pengujian Efek Analgetik 
Penelitian ini terdiri dari 5 kelompok perlakuan yaitu kontrol negatif, kontrol positif, ekstrak etanol daun nangka (Artocarpus heterophyllus Lam.) dengan dosis $100 \mathrm{mg} / \mathrm{kgBB}$, $300 \mathrm{mg} / \mathrm{kgBB}$, dan $600 \mathrm{mg} / \mathrm{kgBB}$. Kelompok I : kontrol negatif (CMC-Na 0,5\%), Kelompok II: kontrol positif (Asam Mefenamat 500mg/kgBB), Kelompok III : Ekstrak etanol daun nangka $100 \mathrm{mg} / \mathrm{kgBB}$, Kelompok IV :
Ekstrak etanol daun nangka 300 $\mathrm{mg} / \mathrm{kgBB}$ Kelompok V : Ekstrak etanol daun nangka $600 \mathrm{mg} / \mathrm{kgBB}$

Setelah diberi perlakuan dosis tunggal peroral, 30 menit kemudian mencit diberi perangsang nyeri, yaitu dengan pemberian asam asetat $1 \%$. Kemudian diamati geliat karakteristik dihitung tiap 5 menit selama 60 menit.

\section{ANALIS DATA}

Data penelitian berupa jumlah geliat kumulatif digunakan untuk menghitung daya analgetik yang dinyatakan sebagai \%proteksi dengan rumus sebagai berikut :

Keterangan : $\mathrm{P}=$ Jumlah kumulatif geliat hewan uji setelah pemberian obat

$\%$ penghambatan terhadap geliat $=100-(\mathrm{P} / \mathrm{K}) \times 100$

$\mathrm{K}=$ Jumlah rata-rata geliat hewan uji kelopok kontrol.

Setelah data persen proteksi diperoleh kemudian dilakukan test Kolmogorov-Smirnov, test ini dilakukan untuk mengetahui apakah data yang diperoleh terdistribusi normal atau tidak. Jika data terdistribusi normal maka dilanjutkan uji homogenitas varian. Jika varian homogen maka dilanjutkan dengan analisis statistik parametrik yaitu analisis varian (ANOVA) satu jalan dengan taraf kepercayaan 95\% menggunakan SPSS versi 21 for windows. Maksud dilakukannya uji ANOVA yaitu untuk mengetahui apakah ada perbedaan yang 30 bermakna atau tidak antar kelompok perlakuan, kemudian dilanjutkan dengan uji LSD (Least Significant Difference). Uji LSD ini untuk mengetahui perbedaan bermakna (signifikasi) atau tidak antar dua kelompok perlakuan yang dibandingkan. (Pratita, 2008).

Analisis Of Variance atau ANOVA merupakan salah satu uji parametrik yang berfungsi untuk memedakan nilai rata-rata lebih dari dua kelompok data dengan cara membandingkan variansinya. Prinsip uji Anova adalah melakukan analisis variabilitas data menjadi dua sumber variasi yaitu variasi didalam kelompok (within) dan variasi antar kelompok (between). Bila variasi within dan between sama ( nilai perbandingan tidak ada perbedaan. Sebaiknya bila variasi antar kelompok lebih besar darivariasi dalam kelompok, nilai mean yang 
dibandingkan menunjukan adanya perbedaan (Canindera, 2016).

Uji Anova dapat dibagi menjadi dua jenis berdasarkan jumlah variabel yang diamati, yaitu One Way Anova dan Two Way Anova. One Way Anova digunakan bila satu variabel yang ingin diamati. Sedangkan Two Way Anova digunakan apabila terdapat dua variabel yang ingin diamati. Uji Anova dapat digunakan unutk menyelidiki apakah ada pengaruh perlakuan terhadap respon penelitian. Ujiuji yang dapat digunakan antara lain uji masing-masing perlakuan dan uji interaksi antar perlakuan (Canindera, 2016)

\section{HASIL DAN PEMBAHASAN}

Tabel 1. Jumlah geliat Kumulatif Mencit (Mus musculus)Tiap 5 Menit Selama 1 Jam Setelah Pemberia Ekstrak Etanol Daun Nangka (Artocarpus heterophyllus Lam.).

\begin{tabular}{|l|l|}
\hline \multicolumn{1}{|c|}{ Kelompok Uji (mg/kgBB) } & Rata-rata Persen Proteksi Geliat $(\mathrm{X} \pm \boldsymbol{S} \boldsymbol{E})$ \\
\hline EEDN 100mg/kgBB & $122,00 \pm 17,00$ \\
EEDN 300mg/kgBB & $80,00 \pm 8,18$ \\
EEDN 600mg/kgBB & $57,00 \pm 11,93$ \\
Na-CMC 0,5\% & $171,33 \pm 6,69$ \\
Asam Mefenamat 500mg/kgBB & $60,00 \pm 14,52$ \\
& \\
\hline
\end{tabular}

Keterangan :

EEDN = Ekstrak Etanol Daun Nangka

$\mathrm{X}=$ Mean (Rata-rata); SE $=$ Standard Error

Tabel 2. Presentase Proteksi Geliat Pada Mencit (Mus musculus) Kelompok Perlakuan Ekstrak Etanol Danun Nangka (Artocarpus heterophyllus Lam.)

\begin{tabular}{|l|l|}
\hline \multicolumn{1}{|c|}{ Kelompok Uji $(\mathrm{mg} / \mathrm{kgBB})$} & Rata-rata Persen Proteksi Geliat $(\mathrm{X} \pm \boldsymbol{S} \boldsymbol{E})$ \\
\hline EEDN 100mg/kgBB & $28,79 \pm 9,92$ \\
EEDN 300mg/kgBB & $53,31 \pm 4,77$ \\
EEDN 600mg/kgBB & $53,31 \pm 4,77$ \\
Asam Mefenamat 500mg/kgBB & $66,70 \pm 6,98$ \\
\hline
\end{tabular}

Keterangan :

$\mathrm{EEDN}=$ Ekstrak Etanol Daun Nangka

$\mathrm{X}=$ Mean (Rata-rata); SE $=$ Standard Error 


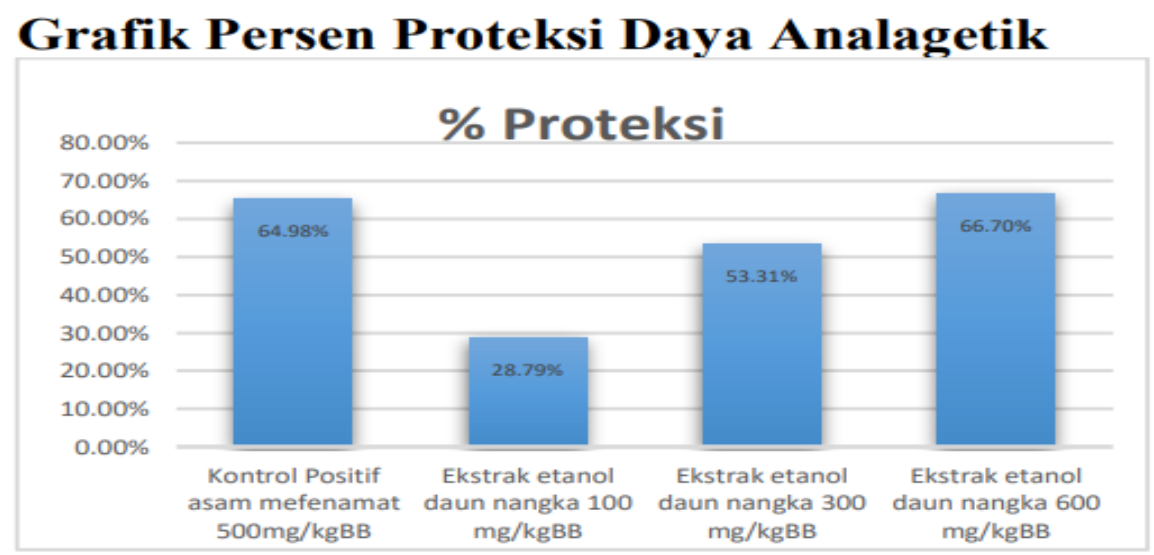

Nyeri adalah perasaan sensoris dan emosional yang tidak nyaman, berkaitan dengan (ancaman) kerusakan jaringan. Keadaan psikis sangat memengaruhi nyeri, misalnya emosi dapat menimbulkan sakit (kepala) atau memperhebatnya, tetapi dapat pula menghindarkan sensasi rangsangan nyeri. Nyeri merupakan suatu perasaan subjektif pribadi dan ambang toleransi nyeri berbeda-beda setiap orang. Batas nyeri untuk suhu adalah konstan, yakni pada 44-45 ${ }^{\circ} \mathrm{C}$ (Tjay dan Rahardja, 2007).

Nyeri timbul jika rangsangan mekanik, termal, kimia atau listrik melampaui suatu nilai ambang tertentu (nilai ambang nyeri). karena itu menyebabkan kerusakan jaringan dengan pembebasan yang disebut senyawa nyeri (mediator nyeri) dan menyebabkan perangsang reseptor nyeri (Sariana, 2011).

Analgetik atau obat penghilang nyeri adalah obat-obat yang mengurangi atau melenyapkan rasa tanpa menghilangkan kesadaran (Sariana,
2011). Analgetik adalah senyawa dalam dosis terapuetik meringngankan atau menekan rasa nyeri, tanpa memiliki kerja anastesi umum. Berdasarkan potensi kerja, mekanisme kerja dan efek samping analgetik dibedakan dalam 2 kelompok yaitu analgetik yang berkhasiat kuat, bekerja pada pusat (hipoanalgetik, kelompok opiat) dan analgetik bersifat lemah (sampai sedang) bekerja terutama pada perifer (Pratita, 2008).

Pada penelitian ini digunakan metode maserasi dengan cara mengekstraksi simplisia daun nangka (Artocarpus heterophyllus Lam.) ditimbang sebanyak 500 gram kemudian dimasukan kedalam bejana maserasi dan ditambahkan etanol 96\% sebanyak 4 liter. Setelah 3 hari cairan penyari diganti dengan etanol $96 \%$ yang baru sebanyak 4 liter. Pergantian penyari sebanyak 1 kali setiap 3 hari dengan jumlah penyari yang sama. Ekstrak cair etanol daun nangka (Artocarpus heterophyllus Lam.) kemudian dikumpulkan dan diuapkan 
cairan penyarinya hingga diperoleh ekstrak kental (Sariana, 2011).

Pada Pengujian efek analgetika dilakukan dengan menggunakan metode rangsang kimia. Dimana metode ini cukup peka untuk pengujian analgetika, obat yang mempunyai efek analgetika lemahpun dapat memberikan hasil positif. Keuntungan lain dari metode tersebut yaitu sensitif, sederhana. Selain itu, bahan dan alat yang digunakan dalam metode ini mudah didapatkan, murah dan waktunya relatif singkat Pratita, 2008). Sebelum perlakuan masing-masing mencit dipuasakan selama 8-12 jam untuk menghindari kemungkinan adanya pengaruh makanan terhadap kandungan bahan yang berkhasiat pada daun nangka (Artocarpus heterophyllus Lam.) yang dapat mempengaruhi efek analgetik yang ditimbulkan. Digunakan mencit putih jantan dengan alasan kondisi biologisnya stabil bila dibandingkan dengan mencit betina yang kondisi biologisnya dipengaruhi masa siklus etrus. Disamping keseragaman jenis kelamin, dan digunakan juga hewan uji yang mempunyai keseragaman berat badan (antara 20-30 gram), dan umur (3-4 bulan). Hal ini bertujuan untuk memperkecil variabilitas biologis antara hewan uji yang digunakan, sehingga dapat memberikan respon yang relatif lebih seragam terhadap rangsang kimia yang digunakan dalam penelitian ini. Pengelompokan hewan uji dilakukan secara acak, maksudnya adalah dari setiap anggota masing-masing kelompok perlakuan memiliki kesempatan yang sama untuk dijadikan sampel. (Sariana, 2011).

Uji efek analgetik ekstrak etanol daun nangka(Artocarpus heterophyllus Lam.), pertama-tama disiapkan 15 ekor mencit jantan lalu puasakan dan ditimbang kemudian di kelompokan menjadi 5 kelompok dimana tiap 1 kelompok terdiri dari 3 ekor mencit, dari ke 5 kelompok diberi perlakuan kontrol negatif Na-CMC 05\%, kontrol positif asam mefenamat $500 \mathrm{mg} / \mathrm{kgBB}$, dan perlakuan ekstrak dengan dosis 100 $\mathrm{mg} / \mathrm{kgBB}, \quad 300 \mathrm{mg} / \mathrm{kgBB}$, dan 600 $\mathrm{mg} / \mathrm{kgBB}$ secara oral. Kemudian 30 menit kemudian di induksi perangsan nyeri asam asetat $1 \%$ secara intraperitoneal. Pemberian asam asetat $1 \%$ akan merangsang pembentukan prostaglandin sehingga menimbulkan rasa nyeri pada hewan percobaan. Asam asetat dapat memberikan suasana asam dengan melepaskan ion $\mathrm{H}+$ yang berperan sebagai mediator nyeri yang mempengaruhi kerja system saraf.

Pemberian ekstrak etanol daun nangka (Artocarpus heterophyllus Lam) secara per oral dengan volume pemberian dalam beberapa konsentrasi $100 \mathrm{mg} / \mathrm{kgBB}, \quad 300 \mathrm{mg} / \mathrm{kgBB}$ dan $600 \mathrm{mg} / \mathrm{kgBB}$ serta diberikan asam mefenamat $500 \quad \mathrm{mg} / \mathrm{kgBB}$ sebagai pembanding karena obat ini memiliki aktivitas dengan jalan menghambat enzim siklooksigenase sehingga pembentukan prostaglandin terhambat dan Na-CMC 05\% sebagai kontrol untuk memperlihatkan adanya perbedaan yang nyata terhadap gerakan geliat pada hewan 
uji. Lalu dihitung geliat pada masingmasing kelompok dan jumlah geliat mencit dihitung tiap 5 menit selama 1 jam. Data \% Proteksi yang diperoleh terlebih dahulu diuji normalitasnya dengan Penelitian ini dilakukan untuk mengetahui efek analgetika dari ekstrak etanol daun nangka ( Artocarpus heterophyllus Lam.) dengan dosis 100 $\mathrm{mg} / \mathrm{kgBB}, 300 \mathrm{mg} / \mathrm{kgBB}$, dan dosis 600 $\mathrm{mg} / \mathrm{kgBB}$ Cara menghitung satu geliat mencit yaitu ditandai dengan satu kali mencit berkontraksi dari dinding perut, kepala dan kaki ditarik kebelakang hingga abdomen menyentuh dasar dari ruang yang ditempatinya. Evaluasi efek analgetik dapat diamati dengan melihat gerakan geliat tersebut dan frekuensi gerakan dalam waktu tertentu menyatakan derajat nyeri yang dirasakan (Pratita,2008).

Pada penelitian ini digunakan 2 kelompok kontrol, yaitu kontrol positif dan kontrol negatif. Kontrol negatif menggunakan CMC-Na 0,5\%. Kontrol positif menggunakan asam mefenamat $500 \mathrm{mg}$ karena asam mefenamat merupakan derivat antranilat juga berkhasiat sebagai analgetik yang cukup baik dan banyak digunakan sebagai anti nyeri dengan cara menghambat sintesa prostaglandin dalam jaringan tubuh dengan menghambat enzim siklooksigenase sehingga mempunyai efek analgetik (Tjay, 2007). Asam senyawa analgetika non-narkotik yang diperdagangkan dan digunakan secara luas. Kontrol positif disini berfungsi untuk membandingkan daya analgetika dengan sampel yang diteliti, juga dapat digunakan untuk membuktikan kevalidan dari metode yang digunakan. Hasil jumlah geliat kumulatif mencit tiap 5 menit selama 1 jam dapat dilihat pada tabel 1. Pada tabel 1 menunjukkan bahwa perlakuan Asam mefenamat dan perlakuan ekstrak etanol daun nangka dosis $300 \mathrm{mg} / \mathrm{kgBB}$ dan $600 \mathrm{mg} / \mathrm{kgBB}$ dapat menurunkan geliat mencit hingga berkurang lebih dari 50\% dibanding kontrol negatif, ini berarti perlakuan asam mefenamat dan ekstrak etanol pada daun nangka dosis $300 \mathrm{mg} / \mathrm{kgBB}$ dan 600 $\mathrm{mg} / \mathrm{kgBB}$ mempunyai efek analgetika. Sedangkan pada perlakuan ekstrak etanol dosis $100 \mathrm{mg} / \mathrm{kgBB}$ menunjukkan penurunan geliat mencit kurang dari $50 \%$ dibanding kontrol negatif, ini berarti pada dosis tersebut tidak mempunyai efek sebagai analgetika. Suatu obat dikatakan mempunyai aktifitas sebagai analgetika bila mampu menurunkan jumlah geliat mencit sebesar 50\% dari jumlah geliat pada kelompok kontrol negatif (Pratita, 2008). Dari data geliat kumulatif mencit msing-masing kelompok perlakuan selanjutnya $\%$ proteksi, hasil dapat dilihat pada tabel 2. . Menunjukan bahwa setiap kelompok perlakuan menunjukan \% proteksi yang berbeda-beda tiap peringkat dosisnya. Presentasi rata-rata tertinggi pada dosis 66,70 \% yaitu dosis ke-3. Presentase proteksi rata-rata kurang dari $50 \%$ di banding kontrol negatif pada $28,8 \%$ yaitu dosis ke-1. Pada dosis ke-2 yaitu $53,31 \%$. Dari dosis ke-2 dan ke-3 positif sebagai analgetik karena proteksinya lebih $>50 \%$. 
Uji Kolmogorov-Smirnov untuk mengetahui apakah data telah terdistribusi normal atau tidak dan uji homogenitas varian apakah varian homogeny atau tidak. Data terdistribusi normal maka dilanjutkan dengan uji statistik parametik Analisis Varian ( ANAVA) satu jalan dengan mengunakan SPSS for windows versi 21 dengan taraf kepercayaan 95\% untuk mengetahui apakah data tersebut memiliki perbedaan bermakna antara seluruh kelompok perlakuan. Setelah ANAVA satu jalan dilanjutkan dengan uji LSD untuk mengetahui perbedaan antara 2 kelompok perlakuan. Hasil ANAVA satu jalan akan menunjukan perbedaan yang bermakna jika p0,05.

Dari Tabel 2. Menunjukan Bahwa dengan meningkatnya dosis ekstrak etanol daun nangka (Artocarpus heterophyllus Lam.) akan meningkatkan persen proteksinya. Dalam penelitian ini rata-rata persen proteksi sebesar $66,74 \%$ pada dosis $600 \mathrm{mg} / \mathrm{kgBB}$ merupakan

\section{KESIMPULAN}

penelitian yang telah dilakukan dapat disimpulkan bahwa ekstrak etanol daun nangka (Artocarpus heterophyllus Lam.) memiliki efek analgetik dan terbesar pada dosis $600 \mathrm{mg} / \mathrm{kgBB}$, mempunyai persen proteksi sebesar yaitu $66,70 \%$.

\section{DAFTAR PUSTAKA}

Ansel, H.C., 1989, Pengantar Bentuk Sediaan Farmasi, diterjemahkan persen proteksi tertinggi sedangkan persen proteksi $28,8 \%$ pada dosis 100 $\mathrm{mg} / \mathrm{kgBB}$ merupakan persen proteksi terendah.

$\begin{array}{lllr}\text { Data } & \text { persen } & \text { proteksi } & \text { yang } \\ \text { diperoleh terlebih } & \text { dahulu } & \text { diuji } \\ \text { normalitasnya } & \text { dengan } & \text { uji }\end{array}$
KolmogorovSmirnov untuk mengetahui distribusi data. Hasil uji memperlihatkan data terdistribusi normal dengan nilai sebesar 0,968 (0,96> 0,005). Pada uji homogenitas varian diperoleh hasil signifikan 0,408 yang berarti varian homogenkarena hasil diperoleh lebih besar dari 0,005.

Hasil uji Statistik parametik Analis Varian (ANAVA) satu jalan diperoleh hasil yang signifikan. Hal ini ditunjukan dengan nilai signifikan 0,000 yang berarti lebih kecil dari 0,005, sehingga bisa disimpulkan rata-rata \% proteksi tiap kelompok perlakuan memang benarbenar berbeda.

oleh Farida Ibrahim, Asmanizar, Iis Aisyah, Edisi keempat, Jakarta, UI Press.

Canindera Costa, 2016. Uji Aktivitas Analgetik Senyawa 4Bromobenzoilurea Pada Mencit Putih (Mus musculus) Dengan Metode Wrthing Test. Fakultas Farmasi Universitas Airlangga Departemen Kimia Farmasi : Surabaya. 
Depkes RI. 2000. Parameter Standar Umum Ekstrak Tumbuhan Obat. Departemen Kesehatan Indonesia: Jakarta

Dwi Rizki Ananda, et al., 2016. Aktivitas Analgetik Ekstrak Etanol Daun melinjo (Gnetum gnemon L.) Pada Mencit Putih (Mus musculus) Jantan, Program Studi D3 Farmasi Universitas Muhammadiyah Mataram.

Meustika Dewi, et al., 2014. Uji Aktivitas Analgetik Ekstrak Etanol Dun Pepaya (Carica papaya L.) Pada Mencit Putih Jantan Yang Diinduksi Asam Asetat $1 \%$, Sekolah Tinggi Yayasan Perintis : Padang

Mutschler, E., 1991, Analgetika Dalam Dinamika Obat, 28-30, 177-183, 194-197, Diterjemahkan oleh Widianto, M. B., dan Ranti, A. S., Edisi V, Penerbit ITB, Bandung.

Galuh Nindya Tyas Tusthy, 2007. Uji Efek Analgetik Ekstrak Etanol Daun Senggani (Melastoma polyanthum BL.) Pada Mencit Putih Betina. Fakultas Farmasi Universtitas Sanata Dharma : Yogjakarta.

Ilmida Husnia, 2010. Uji Efek Analgetik Daun Seledri (Apium graveolens L.) Pada Mencit, Fakultas Kedokteran Universitas Sebelas Maret : Surakarta

I Wayan Suirta, et al., 2015. Isolasi Dan Identifikasi Senyawa Golongan Flavonoid Pada Daun Nangka (Artocarpus heterophyllus Lmk)
Dan Aktifitas Antibakteri terhadap Bakteri Staphylococcus, Jurusan Kimia Universitas Udayana, Bukit Jimbaran : Bali.

Prasetyo, N.S. 2010. Konsep Dan Proses Keperawan Nyeri. Graha Ilmu: Yogyakarta

Price, A. S. dan Wilson, M. L. 2005. Patofisiologi Edisi 6. EGC: Jakarta.

Rahmi Yulia, et al., 2017. Kemampuan Antibakteri Ekstrak Etanol Daun Nangka (Artocarpus heterophyllus Lam.) Terhadap Escherichia coli, Jurusan Biologi FMIPA Universitas Mulawarman : Samarinda.

Rini Susiana, et al., 2016. Panduan Praktis Menanam 28 Buah Tanaman Terpopuler di Pekarangan Ed I. Penerbit ANDI : Yogjakarta.

Susianto Pangestu \& Triswanto Sentat, 2016. Uji Efek Analgetik Ekstrak Etanol Daun Kersen (Muntingia calabura) Pada Mencit Jantan (Mus musculus) Dengan Induksi Nyeri Asam Asetat, Akademi Farmasi : Samarinda

Sariana, 2011. Uji Efek Analgetik Dari Infusa Daun Asam Jawa (Tamarindus indika Linn.) Pada Mencit (Mus musculus). Jurusan Farmasi Fakultas Ilmu Kesehatan Universitas Islam Negeri Alauddin : Makassar.

Tjay, H. T. dan Rahardja, K. 2007. ObatObat Penting Edisi ke Enam. 
Departemen Kesehatan Republik

Indonesia: Jakarta. 